The author made this article openly available online. Please tell us how this access affects you. Your story matters.

Daniel Shore, "Was It for This? Influence, Archive, and Network," Modern Philology 113, no. 3 (February 2016): 398-421.

Collection Permanent Link: http://hdl.handle.net/10822/1042301

(C) 2016 The University of Chicago Press

This material is made available online with the permission of the author, and in accordance with publisher policies. No further reproduction or distribution of this copy is permitted by electronic transmission or any other means. 


\title{
Was It for This? Influence, Archive, and Network
}

\author{
DANIEL SHORE \\ Georgetown University
}

\begin{abstract}
And what is Poetic Influence anyway? Can the study of it really be anything more than the wearisome industry of source-hunting, of allusioncounting, an industry that will soon touch apocalypse anyway when it passes from scholars to computers? ${ }^{1}$
\end{abstract}

Harold Bloom's question in The Anxiety of Influence (1973) is at once derisive and prophetic. Derision is directed at the intellectual wage laborers who perform the nearly mechanical task of recording the way words and phrases, plots and characters, formulas and conventions move between literary works. For these laborers, Bloom prophesies a radical transformation in the means of scholarly production. Like the manufacturing jobs replaced by increasing automation, this "industry" will eventually be populated solely by weariless computers that can better perform the chores of "source-hunting" and "allusion-counting." The move "from scholars to computers" is apocalyptic because with it the typical study of "Poetic Influence" will finally become the spiritless activity, mechanical in truth, it had always been.

Bloom's purpose in envisaging the unraveling of the source-hunting industry is primarily to clear room for his own theory of poetic influence, which replaces sources with Oedipal fathers and allusions with struggles for priority, yet as far as prophecies go, his has fared well. Computers are indeed transforming the means of scholarly production, the conditions of literary-critical labor, and especially the study of influence, as work by numerous digital humanists such as David Bamman, Gregory Crane, Franco Moretti, Matthew Jockers, and others amply shows. ${ }^{2}$ But while Bloom's

1. Harold Bloom, The Anxiety of Influence (Oxford University Press, 1973), 31.

2. For "big data" approaches to literary influence, see David Bamman and Gregory Crane, "Discovering Multilingual Text Reuse in Literary Texts," White Paper (Perseus Digital Library, 2009), www.perseus.tufts.edu/publications/2009-Bamman.pdf; David A. Smith, Ryan Cordell, and Elizabeth Maddock Dillon, "Infectious Texts: Modeling Text Reuse in Nineteenth-Century Newspapers," Proceedings of the Workshop on Big Humanities (Santa Clara, CA: IEEE Computer (C) 2016 by The University of Chicago. All rights reserved. 0026-8232/2016/11303-0006\$10.00 
prophecy captures the profundity of the change, it nevertheless misconstrues its character. This essay offers a corrective vision in which the consequence of digital tools for the study of influence is less apocalypse than revelation. Labor does not merely "pass" from scholars to computers. Nor do computers simply allow us to do what we already do with greater speed and efficiency. Rather, computers have the capacity to deepen, complicate, systematize, and ultimately transform the study of influence. A change in the conditions of academic labor amounts, in this case, to a change in the possibilities of understanding. More specifically, full-text searchable archives like Google Books allow us to turn our attention from the local task of "hunting" and "counting" to the systematic project of discovering and reassembling literary networks of diffusion. Modeled on the "actor networks" of the sociologists Bruno Latour and John Law, such networks reveal the reductionist assumptions that underlie many of influence study's basic concepts-concepts as basic as "commonplace," "source," "author," and "text." By helping us to reassemble networks of diffusion, digital tools allow us to do justice to the plurality, materiality, and irreducible heterogeneity of literary influence.

As a case study in reassembling a network of diffusion, this essay will focus on a phrase that has already received intense critical attention: "Was it for this," which initiates the poem that became the seed of William Wordsworth's The Prelude (1850). Attending at some length to previous scholarship on the phrase's origins will give us a starting point for further investigation, and it will also allow us to differentiate the digital study of influence from its predecessors. An untitled draft manuscript fragment of 150 lines that Wordsworth composed in Germany in October of 1798 begins midline and perhaps midsentence:

was it for this

That one, the fairest of all rivers, loved

\footnotetext{
Society Press, 2013), www.ccs.neu.edu/home/dasmith/infect-bighum-2013.pdf; and Matthew Jockers, Macroanalysis (Urbana: University of Illinois Press, 2013), whose chapter titled "Influence" (154-68) says much about measuring similarity but virtually nothing about influence as such.

3. See Bruno Latour, Reassembling the Social: An Introduction to Actor-Network Theory (Oxford University Press, 2005). Much recent digital humanities work has sought to reconstruct and analyze networks. See Franco Moretti, "Network Theory, Plot Analysis," in Distant Reading (New York: Verso, 2013), 211-40; David K. Elson, Nicholas Dames, and Kathleen R. McKeown, "Extracting Social Networks from Literary Fiction," in Proceedings of the 48th Annual Meeting of the Association for Computational Linguistics (Stroudsburg, PA: Association for Computational Linguistics, 2010), 138-47, www1.cs.columbia.edu/ delson/pubs/ACL2010-ElsonDamesMc Keown.pdf; and Ed Finn, "Becoming Yourself: The Afterlife of Reception," Stanford Literary Lab Pamphlet 3 (2011), litlab.stanford.edu/LiteraryLabPamphlet3.pdf, who builds "networks of recommendations based on consumer purchases drawn from Amazon" and from co-occurrences of book titles in "professional and consumer reviews" (5).
} 
To blend his murmurs with my nurse's song, And from his alder shades and rocky falls, And from his fords and shallows, sent a voice To intertwine my dreams? For this ...?

$$
(\text { Lines } 1-6)^{4}
$$

Line 20 rings the note again: "Was it for this that I, a four years' child ... / Basked in the sun, or plunged into their streams?" (20-23). The question serves not only as introduction but also, in the truncated variation, "For this," as structuring refrain. The second verse paragraph begins, "For this in springtime" (30), and the fourth, "For this, when on the withered mountain-slope" (76). When Wordsworth incorporated the draft fragment into the two-part Prelude of 1799, he jettisoned or wholly altered many of its lines, yet he still began the poem with "Was it for this." The 1804, 1805, and 1850 versions of the Prelude retain the phrase but relocate it some 270 lines into the first book, to a different context where it no longer serves an inaugural or structuring role.

The scholarly search for the sources of William Wordsworth's question began in earnest on April 18, 1975, when a letter to the editor by Jonathan Wordsworth (the great-great-great nephew of the poet and a Romanticist at Oxford) appeared in the Times Literary Supplement. The letter begins, "Sir,May I ask for your readers' help over one of the odder Prelude echoes?" before offering Alexander Pope's Rape of the Lock (1712) as one possible source:

Was it for this you took such constant Care

The Bodkin, Comb, and Essence to prepare;

For this your Locks in Paper-Durance bound,

For this with tort'ring Irons wreath'd around?

For this with Fillets strain'd your tender Head,

And bravely bore the double Loads of Lead?

(4.97-102)

While it is "inconceivable," the letter continues, that Wordsworth did not know Pope's lines, he nevertheless wonders if there is "in fact a shared classical source."

Other readers were quick to heed the call for help. Less than a month later the Harvard scholar Walter Kaiser wrote in with an echo in W. B. Yeats's

4. William Wordsworth, The Prelude: The Four Texts (1798, 1799, 1805, 1850), ed. Jonathan Wordsworth (New York: Penguin, 1995), 3. The draft fragment is transcribed from MS JJ. Unless otherwise noted, all quotations from the various versions of The Prelude are from this volume, with line numbers given parenthetically.

5. Jonathan Wordsworth, letter to the editor, Times Literary Supplement (hereafter TLS), April 18, 1975, 413. 
"September 1913" (1913): "Was it for this the wild geese spread / The grey wing upon every tide?" 6 On June 6 the editorial page featured two further replies. The first, from John Woolford, nominates a passage from John Milton's Samson Agonistes (1671) spoken by Samson's father, Manoa: "For this did the angel twice descend? For this / Ordained thy nurture holy, as of a plant; / Select, and sacred?" (361-62). ${ }^{7}$ He argues that Milton's omission of the initial "Was it ..." is "unimportant weighed against Wordworth's situation and Samson's"-both have failed to fulfill their earlier promise-and he asks whether Pope's passage may not also "be derived from Samson," especially since "it is concerned with precisely the loss of hair which brought about Samson's downfall." In the second reply Jonathan Wordsworth updates readers on the progress of his investigation. ${ }^{8}$ He acknowledges Yeats's echo and adds Wilfred Owen's "Futility" (1918) — "Was it for this the clay grew tall?"- before addressing a further source, brought to his attention by a private letter from Henry Woudhuysen, then an undergraduate. "Equidistant between Pope and Wordsworth," he writes, is William Shenstone's "Elegy XVIII" (1764): "Was it for this, by constant vigils worn, / I met the terrours of an early grave? / For this ... / For this ....” Despite having amassed a small collection of uses, Jonathan Wordsworth nevertheless continues "to think there probably was a source" behind all of them, most likely "classical." He offers one Latin parallel, Aeneid (19 BCE) 2.664, "hoc erat, alma parens" (Was it for this, nurturing mother), but cautions, "the initial question is not developed either by Virgil, or by Dryden" in his translation.

Jonathan Wordsworth shared further updates in July. His own reading had yielded "an important link in the English chain," the eighteenthcentury Scottish poet James Thomson's "Autumn" (1730): "And was it then for this you roam'd the Spring / . . for this you toil'd / . . for this sad fate?" Thomson's poem offers a blank verse counterpart to Pope's heroic couplets, on the basis of which Jonathan Wordsworth hypothesizes a split tradition: "One might guess that Shenstone derives from Thomson, and that [Richard] Jago (The Goldfinches, An Elegy [1747]; sent by Roger Lonsdale) and Byron (Don Juan [1819] 1.148ff; sent by Ian Donaldson) come from Pope." Though doubtless aware of Pope, Wordsworth is "more likely ... to be drawing on Thomson." 10

In September of that year Howard Erskine-Hill wrote in to propose that Ludovico Ariosto's Orlando Furioso (1516) provides "an earlier and more exact analogue" than those previously mentioned. Melissa, disguised as

6. Walter Kaiser, letter to the editor, TLS, May 9, 1975, 512.

7. John Woolford, letter to the editor, TLS, June 6, 1975, 627.

8. Jonathan Wordsworth, letter to the editor, TLS, June 6, 1975, 627.

9. Henry Woudhuysen, email correspondence with the author, June 4, 2012.

10. Jonathan Wordsworth, letter to the editor, TLS, July 11, 1975, 778. 
Ruggiero's sage tutor Atlanta, reproaches the hero for luxuriating in the palace of the sorceress Alcina:
È questo dunque il frutto ch'io
lungamente atteso ho del sudor mio?
di medolle già d'orsi e di leoni
ti porsi io dunque li primi alimenti

$(7.56-59)$

The similarity to Wordsworth's phrase is not particularly evident in the Italian, but it is unmistakable in the first English translation of Ariosto that John Harington published in 1591:

What was't for this that I in youth thee fed,

With marrow of the Beares and Lions fell?

Erskine-Hill cautions that accepting this source does not "deny the central position, in the descent thus revealed, of Manoa's question to Samson"; rather, Wordsworth, Milton, and Pope may all have alluded to this moment in the Furioso. In any event, he suggests, the connection to Ariosto reveals the importance of "heroic story" to The Prelude..$^{11}$

In November of 1977 Jonathan Wordsworth used a review of Stephen Parrish's edition of The Prelude to tie up the loose ends of the correspondence he had begun over two years earlier. After quoting Wordsworth's opening question, he endorses Woolford's contribution, acknowledging that, while other sources are available, "Milton's lines" from Samson Agonistes are "especially important," since in failing to write The Recluse Wordsworth is similar to Samson, who failed to free the Israelites. Jonathan Wordsworth closes the discussion of "Was it for this" in Bloomian fashion, asserting, "If ever there was a case of the anxiety of influence it must be this," regardless of whether the "echo" was "conscious" or not, and asks us to imagine "Milton's presence looking over the effete's [sic] shoulder as he writes."

\section{THE SOURCE AND THE COMMONPLACE}

Though the TLS correspondence is somewhat haphazard, it nevertheless operates under a clear set of guiding presuppositions and aims that it shares with "source-hunting" more generally. ${ }^{13}$ There is, from the outset, an acknowledgment of multiple possible sources; Pope is offered only as the first of

11. Howard Erskine-Hill, letter to the editor, TLS, September 26, 1975, 1094.

12. Jonathan Wordsworth, "Fructifying Spots of Time," TLS, November 11, 1977, 1330.

13. For a discussion of the role of source study and influence hunting in the disciplinary history of literary studies, see Ted Underwood, Why Literary Periods Mattered: Historical Contrast and the Prestige of English Studies (Stanford University Press, 2013), 119-21, 124-27. 
others to come. Yet beneath the acknowledgment of plurality is the drive toward discovering a single, definitive precursor, "a source" or, as Woolford puts it, "the source," rather than sources. In keeping with this drive, multiple appearances of the phrase are treated as the offspring of a single predecessor. Jonathan Wordsworth begins the investigation as a search for a "shared classical source," where classical initially means Greek or Latin but eventually comes, in scare quotes, to mean definitive and aboriginal, needing no further source, such that Milton can be described as the "classical" source of both Pope and Wordsworth. Erskine-Hill's discovery of the phrase in Harington's translation of Ariosto allows him to propose a still earlier, shared source for all three poets.

The "importance" of a source is evaluated through similarity-not only similarity of phrasing, which is prerequisite, but of situation, subject matter, generic form, and so on. The difference between Milton's "For this" and Wordsworth's "Was it for this" is ultimately outweighed by the similarity between Samson's situation and Wordsworth's. Because they wrote rhyming verse, Jago and Byron are thought to look back to Pope, whereas Wordsworth and Shenstone, writing in blank verse, look back to Thomson. Finally, all uses of "Was it for this" prior to Wordsworth are assigned to the category of "source," or, in more tentative formulations that avoid causal assertion, of "parallel," "analogue," or "echo."

The inquiry into poetic influence that unfolds on the TLS correspondence page drew on the public and private labor of a broad community of scholars from multiple fields, disciplines, institutions, and countries. Ten named and some number of unnamed investigators turned up eleven sources (depending on how one counts), a few of them clearly significant, as well as two subsequent echoes. While a critic like Bloom would question the intellectual worth of such an investigation, in scholarly terms it was unmistakably productive: the following decades saw numerous articles and book chapters, often by notable scholars, returning to the correspondence to add sources, reconsider influences, and draw on its discoveries for interpretive purposes, making Wordsworth's phrase and its sources one of the most discussed in twentieth-century literary criticism. ${ }^{14}$

14. See, e.g., Stephen Parrish, ed., The Prelude, 1798-1799, by William Wordsworth (Ithaca, NY: Cornell University Press, 1977), 6; John T. Ogden, “Was It for This?,” Wordsworth Circle 9 (1978): 371-72; Leslie Brisman, Romantic Origins (Ithaca, NY: Cornell University Press, 1978), 312-13; Susan Wolfson, The Questioning Presence: Wordsworth, Keats, and the Interrogative Mode in Romantic Poetry (Ithaca, NY: Cornell University Press, 1986), 146-50, 156-57; Geoffrey Hartman, "Was it for this ... ?": Wordsworth and the Birth of the Gods," in Romantic Revolutions: Criticism and Theory, ed. Kenneth R. Johnston et al. (Bloomington: Indiana University Press, 1990), 8-25; John A. Hodgson, "Was It for This . . ?': Wordsworth's Virgilian Questionings," Texas Studies in Literature and Language 33 (1991): 125-36; Robert J. Griffin, Wordsworth's Pope (New York: Cambridge University Press, 1995), 102-7; Simon Bainbridge, "Was it for this 
The participants in the TLS correspondence were under no illusion that they had found all possible sources, parallels, or analogues. Yet they would probably have been surprised to learn how many uses of the phrase they could have discovered with world enough and time-or a good search engine. A Google Books search for the exact phrase, "was it for this," prior to 1798, when Wordsworth composed the lines that burgeoned into The Prelude, returns 2,350 matches. Using the Text Creation Partnership engine to search Early English Books Online returns 153 matches in 118 works, all before 1700. Literature Online returns 176 matches in 228 works prior to 1798, which it breaks down into 63 poems, 101 dramas, and 12 prose texts. ${ }^{15}$ Not all of these matches are genuine. Many are duplicates, especially because they are drawn from archives that cover overlapping periods. Depending on their popularity, some works appear in multiple editions, collections, and anthologies. In some proportion of matches the phrase is not used conventionally, since "Was it for this" was (and remains) a perfectly colloquial phrase that could have been written or spoken by any competent English language user without drawing on previous texts or traditions. In others it has a different syntax, or is used with a different aim, as when the natural philosopher Joseph Glanvill asks, "was it for this man's sin or his Father's [that he was struck blind]?" using "this" as a determiner modifying "man" rather than as a demonstrative pronoun. ${ }^{16}$ Excluding duplicates and false matches leaves, in a conservative estimate, more than a thousand unique uses of the phrase in published English works prior to 1798, though the precise number is ultimately beside the point, especially since it could easily grow as the archives mentioned above expand or as further archives are consulted. What is important, for present purposes, is that a thousand is a big number, bigger than could be made sense of under the investigative presuppositions of the $T L S$ correspondence or of traditional source study more generally. ${ }^{17}$

To the examples uncovered by Jonathan Wordsworth and his interlocutors, digital searches add works by luminaries like Fulke Greville, John Webster, Abraham Cowley, Michael Drayton, John Dryden, Tobias Smollett, John Gay, and Jonathan Swift (or perhaps another of the Scribblerians), as well as by lesser lights like Samuel Brandon, the brothers Francis and John Quarles, Robert Gomersall, Shackerly Marmion, Elkanah Settle, and Ste-

[... ]?': The Poetic Histories of Southey and Wordsworth," Romanticism on the Net 32-33 (2003-4), http://www.erudit.org/revue/ron/2004/v/n32-33/009258ar.html.

15. Google books can be found at https://books.google.com/; Early English Books Online at http://eebo.chadwyck.com/home; Early English Books Online-Text Creation Partnership at http://eebo.odl.ox.ac.uk/e/eebo/; Literature Online at http://literature.proquest .com/.

16. Joseph Glanvill, Lux Orientalis (London, 1667), 51.

17. For an account of what to do with a thousand instances that diverge from the "distant reading" of Franco Moretti (Distant, 43-62), see Daniel Shore, "WWJD? The Genealogy of a Syntactic Form," Critical Inquiry 37 (2010): 1-25, esp. 23-25. 
phen Duck. The male participants in the TLS correspondence mention only male authors, but female authors such as Ann Radcliffe, Eliza Haywood, Aphra Behn (twice, in a fictional love letter and a comedy), and Lady Mary Wroth also used the phrase prior to 1798. "Was it for this" appeared not only in the lyric, dramatic, and heroic poetry mentioned in the correspondence but also in emblem poems, epistolary novels, polemical pamphlets, sermons, newspaper columns, protestant meditations, antipapist polemical tracts, devotional poems, courtesy books, and Gothic romances; in Englishlanguage texts published in Paris, Amsterdam, Edinburgh, Dublin, and Philadelphia, as well as London; used wistfully, tragically, elegiacally, bitterly, reproachfully, satirically, and frequently (to my ear at least) woodenly; by suicidal heroes, jealous villains, disappointed parents, spurned lovers, betrayed empresses, zealous nationalists, fiery revolutionaries, and repentant sinners. In the two centuries preceding the composition of The Prelude one would be nearly as hard pressed to find an author, and especially a poet or playwright, who did not use the phrase as one who did.

A single individual possessing no extraordinary technical skill, sitting alone at a computer with Internet access and a full complement of library subscriptions, can now uncover these uses of the phrase in an afternoon of leisurely searching, though of course doing anything with them-reading, sorting, understanding - takes a more considerable investment. Is this the apocalypse prophesied by Bloom? A thousand odd sources should, to start, challenge the notion that one could, through any further evidence or consideration, arrive at a single, definitive source for Wordsworth's inaugural question. To be sure, some texts do consciously allude or unconsciously borrow from a single source, but the a priori presupposition of such a source is untenable. Wordsworth likely encountered the phrase in a multitude of texts: not only those mentioned in the TLS correspondence but also in a poem by an acquaintance, Francis Wrangham, "The Destruction of Babylon" (1795) $;^{18}$ in Things as They Are, or The Adventures of Caleb Williams (1794), a novel by his early philosophical exemplar, William Godwin; in Ann Radcliffe's The Mysteries of Udolpho (1794); in at least six issues of The Gentleman's Magazine (1731-1922); in four of the poems and plays in Vicesimus Knox's Extracts, Elegant, Instructive, and Entertaining (1785), the standard poetry anthology of the day; and in a host of other texts that he could have read or that scholars have claimed, with varying degrees of confidence, that he actually did read. ${ }^{19}$ Although he encountered the phrase in multiple

18. Duncan Wu proposes Wrangham in Wordsworth: An Inner Life (Oxford: Blackwell, 2002), 120.

19. For the indispensable work on Wordsworth's reading, see Duncan Wu, Wordsworth's Reading, 1770-1799 (Cambridge University Press, 1993). Extracts, Elegant, Instructive, and Entertaining, in Poetry, ed. Vicesimus Knox (London, 1791), 23, 146, 159, 191. See also Bruce Graver, 
places, as Wordsworth sat down to compose the lines that would grow into The Prelude he may have had in mind a single work, or two, or twenty, or indeed none at all-only a mere phrase ringing in his ear, detached from any particular text or author, its plural origins merged, or simplified, or conflated, or forgotten, or half-forgotten. As Ezra Pound puts it, "The domain of culture begins when one HAS 'forgotten-what-book.',20

Nor can we justly elevate one of Wordsworth's predecessors to a decisive role based on similarities of situation, as the TLS correspondence presupposes from the outset. To judge that in composing his opening lines Wordsworth is, for example, more like Milton's Samson, or Ariosto's Ruggiero, or Virgil's Aeneas, or even Pope's Belinda, is to assess the extent of similarity by deciding on the criteria of similarity. If we elect Milton as chief precursor, for example, we have implicitly decided that similarity of phrasing is less important than similarity of situation, and that who is speaking is less important than what is said, since Wordsworth, like Aeneas, asks the question himself, whereas Manoa asks the question for Samson. We must decide, if only tacitly, on further criteria that allow us to judge that Samson's failure to liberate Israel is a closer match than Ruggiero's failure to resist feminine luxuriousness, or that Wordsworth utters the lines with a heroic voice (like Milton and Harington's Ariosto) rather than a pastoral elegiac voice (like Shenstone and Thomson). Such criteria are arbitrary enough when judging three or four texts, but when judging twenty or a hundred much less a thousand they are nonsensical. Even if one could decide on the relevant criteria with which to nominate a single, decisive predecessor, doing so overlooks a still more basic fact. Writers are in the business of wresting phrases from their previous contexts of use and repurposing them. Judging the importance of sources by their similarity neglects the capacity of poets to pluck beautiful fruit from the tree of the other as well as the tree of the same.

If Wordsworth's inaugural question does not have a single origin, conscious or otherwise, does it therefore follow that it is commonplace? In present-day scholarly usage (as opposed to the usage of Aristotle or Renaissance humanists), to describe something as commonplace is to assert that it is pervasive and perhaps to slight it as banal or trite as well. This is clearly true of "Was it for this" in the seventeenth and eighteenth centuries. ${ }^{21}$ The designa-

\footnotetext{
"Duncan Wu's Wordsworth's Reading, 1770-1790 [sic]: A Supplementary List with Corrections," Romanticism on the Net 1 (1996), http:/ / www.erudit.org/revue/RON/1996/v/n1/005711ar. html, which makes further suggestions regarding Wordsworth's reading of Virgil.

20. Ezra Pound, Guide to Kulchur (New York: New Directions, 1938), 134.

21. On the Renaissance use of the term commonplace, see Kathy Eden, Friends Hold All Things in Common: Tradition, Intellectual Property, and the Adages of Erasmus (New Haven, CT: Yale University Press, 2001). On Aristotle's koinoi topoi, see On Rhetoric, trans. George A. Kennedy (New York: Oxford University Press, 1991), 45-47. Present-day uses of the term commonplace are, as it were, commonplace, cutting across critical approaches, including historicisms both new and old.
} 
tion helpfully avoids the error of presupposing that the phrase has a single, identifiable source. It also has the convenience of stopping at the point of acknowledging that the phrase is widespread without probing into why or how it became so. But this is precisely the problem: declaring something commonplace pulls inquiry up short at the boundary of what we already know. The term has allowed the discipline of literary studies to use its knowledge of a thing's pervasiveness to conceal its ignorance of how it came to be pervasive. It lets scholars operate under the assumption that, because they cannot identify the specific, singular somewhere from which an author receives a phrase or idea, it must therefore be from an unspecified everywhere or, in what amounts to the same thing, an idealized nowhere, effectively erasing the material processes of transmission by which the widespread came to be spread so widely. In literary scholarship, the commonplace is the workmanlike companion of Virgil's Fama, Rumor, the god of many mouths, voices, tongues, eyes, and ears, who (mirabile dictu) spreads truth and falsehood far and wide. But Virgil at least knew that Fama is a fictional stand-in for a complex process of diffusion that is only infrequently open to inspection.

Only by material processes of transmission does something widespread come to be spread so widely. ${ }^{22}$ There is no reservoir of cultural material (ideas, words, images, background assumptions, discursive rules, and so forth) independent of concrete mechanisms of diffusion. No utterance reproduces itself without moving matter, without the work of tongues, pens, or presses. Phrases or ideas are "in the air" only in the wholly literal sense that vibrations carry them from mouth to ear; light carries them from surface to eye; or, more recently, radio waves or pulses of light carry them from transmitter to receiver. The drive to identify a single source mistakenly seeks to pierce through a phrase's plurality; by positing it as inexplicably everywhere at once, the category of the commonplace mystifies the materiality of the processes by which a phrase becomes common.

\section{STANDARDS AND FORMULAS}

The thousand-odd uses of "Was it for this" do not merely disabuse us of some widely accepted methodological assumptions; they also call for explanation. Traditional source study has focused on the individual author and the work-its sources, significance, and meaning. Accounting for the phrase's plurality, by contrast, requires a new set of questions: Why did this particular phrase spread so widely? How was it transmitted and by what media? What

22. Compare to Roger Whitson, "Digital Blake 2.0," in Blake 2.0: William Blake in TwentiethCentury Art, Music and Culture, ed. Steve Clark, Tristanne Connolly, and Jason Whittaker (New York: Palgrave, 2012), 41-55, whose object-oriented concept of "network materiality" (46) entails the relationality of matter itself. 
were its variations, how did they arise, and which were influential? Asking these kinds of questions does not make Wordsworth disappear, but it does displace him from the center of investigation. He becomes one (admittedly consequential) node, his debts a subset of edges, in a larger network of diffusion.

Although these questions inquire about the dynamics of a network, they do not obviate close attention to the phrase's verbal intricacies. "Was it for this" is so readily transmissible because of its linguistic form. ${ }^{23}$ The phrase's twin pronouns - the impersonal "it" and demonstrative "this"- hook seamlessly into a wide variety of contexts. It and this are what Roman Jakobson calls "shifters," linguistic signs that gain their indexical meaning (meaning as pointers) from the context in which they are uttered ${ }^{24}$ Unlike aphorisms, maxims, or adages such as "Friends share all things in common," which convey situation-independent meaning, the phrase taken on its own is semantically poor, with was and for serving grammatical rather than lexical functions and it and this pointing only to empty or unspecified particulars.

Yet the phrase's semantic poverty is the condition of its combinatory opulence. While its referential and semantic openness makes it portable, the specificity of its form makes it worth porting. It initiates utterances that fill in, with various degrees of definition, answers to the questions posed by its pronouns. The form of the these utterances is Was it for this [that] X [in order to] $Y$, where $X$ describes a propitious past and $Y$ the deficient present; the $Y$ variable is often left unexpressed or only gestured to (as it were) with a deictic sweep of the hand. For the author sitting down to compose, the phrase offers an instrument of invention or way to begin writing, a "seed phrase" that bears within it a set of complex syntactic, temporal, and narrative relations, as well as the moods, attitudes, and conventional speech acts that go with them-the generative origins, in other words, not simply of a sentence but of an entire dramatic situation. Consider a stanza by Mary Leapor, the daughter of a Northamptonshire gardener who for much of her

23. Because the method of tracing influence demonstrated here takes into account syntax, it diverges from other digital approaches, like topic modeling, word frequency analysis, and semantic cohort methods, that necessarily discard syntax in order to measure the relative frequency or co-occurrence of words in a document. For a sophisticated demonstration and theorization of topic modeling, see Andrew Goldstone and Ted Underwood, "The Quiet Transformation of Literary Studies: What Thirteen Thousand Scholars Could Tell Us," New Literary History 45 (2014): 359-84; for an extended discussion of relative frequency analysis, see Stephen Ramsay, Reading Machines: Toward an Algorithmic Criticism (Urbana: University of Illinois Press, 2011), chaps. 3-5 (32-82); for an application of the semantic cohort method, see Ryan Heuser and Long Le-Khac, "A Quantitative Literary History of 2,958 Nineteenth-Century British Novels: The Semantic Cohort Method," Stanford Literary Lab Pamphlet 4 (2012), litlab.stan ford.edu/LiteraryLabPamphlet4.pdf.

24. Roman Jakobson, "Shifters, Verbal Categories, and the Russian Verb," in Russian and Slavic Grammar: Studies, 1931-1981, ed. Linda R. Waugh and Morris Halle (New York: Mouton, 1984), 42-44. 
short life (1722-46) worked as a domestic servant; the stanza likens the rejection of her play script to the humiliation of an errant child:

Was it for this, O graceless child!
Was it for this you learn'd to spell?
Thy face and credit both are spoil'd:
Go drown thyself in yonder well. ${ }^{25}$

The whole matter of the stanza is anticipated in, and can be folded back into, its initiating phrase: "Was it [learning to spell] for this [the spoiling of thy face and credit both]?" In much the same way that a seed contains the structure of a tree, or that, in Wordsworth's terms, "the child is father of the man," so does the phrase comprehend and structure both the sentence and the situation that follows from it.

In Leapor's poem as elsewhere, the "it" refers to the promise of the past, the "this" to the failure of that promise in the present. Because the phrase retrospectively takes measure of the frailty of human hopes and expectations in the disparity between past and present, it is usually uttered with disappointment, regret, resentment, rage, or despair; speakers use it to initiate the conventional speech acts of mourning, lamenting, complaining, reproaching, and chastising. A range of intricate dramatic situations are tightly coiled into four colloquial, monosyllabic, Anglo-Saxon words: was, it, for, this. In the terms of informatics, these are "stop words," words regularly filtered out before text processing. ${ }^{26}$ While the phrase can initiate the most formal of set pieces and acquires an especially ceremonial character when used as a refrain, it does not sound out of place in the prose of the forum or the marketplace. Meter matters too: it consists of two iambs (Was it for this) or, as need dictates, a trochee and an iamb (Was it for this), allowing it to be easily integrated into the most common verse forms of the day.

The humanist culture of early modern England, obsessed with recovering and imitating classical antiquity, proved highly susceptible to the phrase. Through the work of early translators, it arrived stamped with the most prestigious of associations - not only with the premier form of literary art, the heroic poem, but with that form's most exemplary practitioner, Publius Vergilius Maro. In book 2 of Virgil's Aeneid, after witnessing Troy in flames, Aeneas is rescued by his mother Venus from marauding Greeks. Resolved to die fighting, he returns to his home and bewails his and his family's fate:

hoc erat, alma parens, quod me per tela, per ignis eripis, ut mediis hostem in penetralibus utque

25. Mary Leapor, "Upon her Play Being Returned to her Stain'd with Claret," in Poems by Eminent Ladies, 2 vols. (London, 1755), 2:133.

26. On the history of stop words, see Daniel Rosenberg, "Stop, Words," Representations 127 (2014): 83-92. 
Ascanium patremque meum iuxtaque Creusam alterum in alterius mactatos sanguine cernam?

[Was it for this, gracious mother, that thou savest me amid fire and sword, to see the foe in the heart of my home, and Ascanius, and my father, and Creüsa at their side, slaughtered in each other's blood?] ${ }^{27}$

This lament represents the nadir of Aeneas's fortunes; his hopes are soon restored by a prophecy that his son Ascanius will found the Roman race. But light in Troy gives way to darkness in Carthage. A version of Aeneas's "hoc erat ... quod" appears again in book 4, which relates his love affair with Dido, his eventual departure, and her subsequent suicide. Dido impales herself and casts her dying body on the pyre supposedly meant to immolate the possessions Aeneas has left behind. When Anna, her sister, returns to find her corpse, she despairs:

hoc illud, germana, fuit? me fraude petebas?

hoc rogus iste mihi, hoc ignes araeque parabant?

[Was it for this, sister? Didst thou aim thy fraud at me? Was this for me the meaning of thy pyre, this of thy altar and fires? $]^{28}$

Where Aeneas exclaims "this" ( $h o c$ ) only once, Anna beats out the demonstrative pronoun three times: this ... this ... this. Where his despair gives rise to hope, hers ends in ghastly suicide.

Wordsworth studied Virgil's lines during his education at the Free Grammar School at Hawkshead, which was founded and endowed by the Archbishop of York in the late sixteenth century. ${ }^{29}$ The standard grammar curriculum focused heavily on classical languages and literatures, and especially Latin texts; with some exceptions, this curriculum stayed remarkable stable for nearly four centuries. ${ }^{30}$ Along with Milton, Pope, Dryden, Shenstone, Thomson, Cowley, and Harington-indeed all the male authors of the pre-

27. Latin text and English translation from Virgil, Aeneid, in Eclogues, Georgics, Aeneid 1-6, trans. H. Rushton Fairclough, rev. ed., Loeb Classical Library (Cambridge, MA: Harvard University Press, 1935), 338-39.

28. I have altered the Fairclough Aeneid translation, 440-41, to make evident the parallel with Aeneas's earlier lament.

29. For a study of Wordsworth's classical education see Richard W. Clancey, Wordsworth's Classical Undersong (New York: St. Martin's, 2000), esp. 1-51; T. W. Thompson, Wordsworth's Hawkshead, ed. Robert Woof (London: Oxford University Press, 1970); and Ben Ross Schneiderman, Wordsworth's Cambridge Education (New York: Cambridge University Press, 1957).

30. See M. L. Clark, Classical Education in Britain, 1500-1900 (Cambridge University Press, 1959). Clancey, Undersong, 26, notes that Hawkshead had an unusually intense focus on learning Greek as well as Latin. 
vious two centuries who received a classical education-Wordsworth would have come to know the Aeneid in school through repeated reading, translation, double translation (from Latin to the vernacular and back again), memorization, and imitation. ${ }^{31}$ By putting students on intimate terms with Virgil's Latin poem, the grammar schools of the seventeenth and eighteenth centuries established the conditions for the spread of "Was it for this" throughout the educated English populace.

Evidence of Wordsworth's classical education survives in the first volume of Christopher Pitt's translation of the first four books of the Aeneid, a volume that he owned and shared with his three brothers. ${ }^{32}$ Published in 1736, Pitt's Aeneid was acquired by the Wordsworths as early as 1784 , when William was fourteen years old and, with his father dead a year, newly orphaned. It is likely that William and his brothers used Pitt's Aeneid as a "crib," "pony," or "trot" — an aid to translation that allowed them to complete their lessons without needing to consult a dictionary or Latin grammar. Inscriptions on the volume's flyleaves suggest that they passed the book down from older brother to younger, Richard to William to John to Christopher, so that each could use it to tackle Virgil's Latin at the appointed time in the curriculum. ${ }^{33}$ Pitt's translation has Anna, discovering the body of Dido, wail, "Was it for this my hands prepar'd the pyre / The fatal altar, and the funeral fire?" 34 Even after he finished his schooling, Wordsworth continued his intimacy with the Aeneid. He later acquired and annotated a copy of John Ogilby's Works of Publius Virgilius Maro (1649) and in 1823-24, dissatisfied with existing translations, set out to make his own, though discouragement from patrons, and especially his friend Coleridge, led him to halt the project after completing only the first three books. ${ }^{35}$

The romanticist John Hodgson first noted the Virgilian resonance of Wordsworth's question in 1991, reversing Jonathan Wordsworth's earlier dismissal of the Aeneid. He concludes that Virgil's poem is "the source" for Wordsworth and other English poets who used the phrase or, more exactly, that it contains "two sources," in both the second and fourth books. ${ }^{36}$ Hodgson is surely right that the Aeneid plays an indispensable role in the spread of "Was it for this," but it does not follow that it is the phrase's "source." Most

31. On Wordsworth's early reading of Virgil, see Duncan Wu, "Three Translations of Virgil Read by Wordsworth in 1788," Notes and Queries 37 (1990): 407-9.

32. Virgil's Aeneid, vol. 1, trans. Christopher Pitt (London, 1736). Wordsworth's copy of Pitt's Virgil is now in the collection of Paul F. Betz, who generously allowed me to view it.

33. Wu, Wordsworth's Reading, 140-41.

34. Pitt's translation of Virgil's Aeneid, 228 (4.971-72). See also Duncan Wu, "Three Sources for Wordsworth's Prelude Cave," Notes and Oueries 38 (1991): 298-99.

35. William Wordsworth, Translations of Chaucer and Virgil, ed. Bruce Graver (Ithaca, NY: Cornell University Press, 1998), 155-63, 273.

36. Hodgson, “Was It for This,"” 120. 
obviously, "Was it for this" is an English, not a Latin phrase. It does not have a natural, necessary, or unequivocal Latin counterpart. What Hodgson calls its "two sources" are far from identical. Though Anna echoes Aeneas's "hoc," she does not utter the same words: he begins "Hoc erat ... quod," while she begins "Hoc illud ... fuit." Nor do they utter a classical formula, since the words, syntax (word order as well as grammar), and meter of their questions differ. ${ }^{37}$

Hodgson asserts that "the Englishing of Aeneas's and Anna's questions as 'Was it for this?' would have been straightforward." 38 Yet the history of the Aeneid in English shows that this translation was hardly straightforward, much less necessary or inevitable. James Harrington did not use the phrase in his 1659 translation, nor did Edmund Waller and Sidney Godolphin in theirs. In his influential Aeneid of 1697, Dryden renders Aeneas's lament: "Did you for this unhappy me convey / Through foes and fires to see my house a prey?" (2.903-4). His Anna asks, "Was all that pomp of woe for this prepared?" (4.970). ${ }^{39}$ In translating Virgil Wordsworth himself avoids the full phrase that he had used as the seed of The Prelude a quarter of a century earlier; his Aeneas begins instead with the truncated form: "For this, benignant Mother! Didst thou lead / My steps along a way from danger freed." ${ }^{, 40}$ Even when translators did use the full phrase, they rarely did so for both Aeneas and Anna. Though Pitt's Anna utters "Was it for this," his Aeneas avoids any version of it: "Why, heavenly mother! did thy guardian care / Snatch me from fires, and shield me in the war?"41

"Was it for this" was not from the outset the standard ("straightforward," idiomatic, natural, etc.) English rendering of Virgil's "hoc erat ... quod" or "hoc illud... fuit"- the rendering, that is, from which all others are departures. It only became standard (though never necessary or invariable) through the agency of multiple English translators and other writers. By the middle of the nineteenth century, critical, scholarly, and pedagogical editions of the Latin text would consistently annotate 2.664 as "Was it for this."42

37. On the strict definition of a formula, see Albert B. Lord, The Singer of Tales, ed. Gregory Nagy (Cambridge, MA: Harvard University Press, 2000). Even under a more relaxed definition, Virgil is not using a classical formula, though Anna does echo Aeneas's "hoc."

38. Hodgson, "Was It for This," 132. In order to argue that "Was it for this" is the "straightforward" translation of Aeneas's (and, presumably, Anna's) line, Hodgson must denigrate other translations. Of Dryden's he writes, "Here the initial simplicity, and even the very spirit of these questions, is obscured" (133). He describes Ogilby's 1650 Aeneid as "unidiomatic" and Wordsworth's own 1823-24 translation as "sadly stilted" (135 n. 19).

39. John Dryden, trans., Virgil's “Aeneid” (New York, 1891), 53, 101.

40. Wordsworth, Aeneid 2.892-93, in Graver's edition of Wordsworth's Translations.

41. Pitt, Virgil's Aeneid, 2.893-4.

42. See, for example, Charles Anthon's 1843 edition, The Eneid of Virgil (New York: Harper, 1843), 428, which follows the "standard" translation before adding that the Latin is "more literally" translated as "was it this on account of which." 
But translations of the Aeneid before 1798 show the early, still incomplete stages of this standardization process. The phrase first appears, in a nonstandard form, in Henry Howard, Earl of Surrey's 1557 translation of Aeneas's lament. In the first published blank verse in the English language, Surrey renders Virgil's "hoc erat ..." (2.664-65) as "O sacred Mother! Was it then for this / That you led me through flame, and weapons sharp?" (2.874). ${ }^{43}$ In 1583, translating the same passage into English hexameters rather than the conventional pentameters, Richard Stanyhurst shortens the phrase through syncope: "Was't for this (moother) that mee through danger unharmed / You led?" 44 The truncated reprise, "for this," first appears in the lament of Surrey's Anna: "Sister! for this with craft did you me bourd [deceive]?" (4.900). Though eighteenth-century translators like Pitt did not need to establish "Was it for this" as standard, since earlier translators had effectively completed this process, they maintained it as standard by repeating it. Without such establishment and maintenance, there would be no standard translation and no recognizably Virgilian English phrase that we could speak of as persisting. ${ }^{45}$

Acknowledging the standard as the product of translation rather than its cause does not imply that we should regard Surrey (or Stanyhurst, or the others that follow them) rather than Virgil as the phrase's source but rather that for the study of influence the very concept of source is insufficient to capture all the necessary distinctions. Its etymology suggests the wellspring or fountain from which a river or stream takes its origin. ${ }^{46}$ The same substance, the same liquid, emerges and flows from one text to another. (The liquid metaphor is built as well into the word "influence," from the Latin "fluo, fluere," to flow.) In the TLS correspondence, as in source study more generally, source names a category to which all prior appearances of a phrase can, at least potentially, be consigned. But this category conceals the way a phrase changes as it travels through the literary network, both in its composition, meaning, and use. "Was it for this" only became the phrase that appears in Wordsworth's Prelude (instead of Virgil's "Hoc erat ... quod" or

43. Henry Howard, Earl of Surrey, "Second Book of Virgil's Aeneid," in The Works of Henry Howard, Earl of Surrey, and of Sir Thomas Wyatt the Elder, vol. 1, ed. George Frederick Nott, 2 vols. (London, 1815), 119. Gawin Douglas's 1513 Scots Aeneid, the first to translate the whole poem into a modern Germanic language, renders the lines thus: "Is this the way, my haly moder, that thou / Suld keip me fais and firis passyng throw?" (Gawin Douglas, Virgil's Aeneis, Translated into Scottish Verse [Edinburgh, 1710], 61).

44. The First Four Books of Virgils Aeneis, trans. Richard Stanyhurst (London, 1583), 39.

45. For an example of how standards of measure are the products of networks, see Bruno Latour, We Have Never Been Modern, trans. Catherine Porter (Cambridge, MA: Harvard University Press, 1993), 119-20, and Reassembling the Social, 227-29.

46. OED, s.v. "source," n., def. 3a, http://www.oed.com/. For a brilliant study of the topos of the source and its liquid metaphors, see David Quint, Origin and Originality in Renaissance Literature (New Haven, CT: Yale University Press, 1983). 
Surrey's "Was it then for this") by undergoing a multitude of transformations as it moved from one author, text, language, nation, age, genre, and verse form to another. As the product of multiple agencies, the phrase has an ultimate source or origin in none of them.

Instead of joining the TLS correspondence in regarding all thousandodd pre-1798 uses of the phrase as candidate sources, reassembling a network of diffusion requires that we differentiate them according to their various functional roles. This means enlarging our descriptive vocabulary and, where ready terms are not available, drawing on analogies to nonliterary domains. I suppose that it is sufficient, for example, to say that Surrey is a translator, the first, so far as I can discover, to render a line of the Aeneid in a particular and contingent way. But we lack a ready term to describe a poet who, like Virgil, is the cause of a widespread phrase in a different language. The Aeneid is less like the wellspring of a stream than, to borrow from epidemiology, the disease reservoir (a flock of birds or herd of swine) from which a virus repeatedly crosses over to humans. Asymptomatic in the reservoir, the virus becomes contagious and virulent only in its new (English-speaking) hosts. Or, to vary the analogy, in his translation Stanyhurst is like the early adopter who purchases a new technology before it has become standard, thereby lowering the cost and risk for subsequent buyers. The provenance of such analogies matters less than that they adequately characterize the differentiated roles played by different agencies in the network of diffusion. Of course, in any network agency will not be equally distributed; some actors exercise an outsize influence. Though he never uses the phrase, Virgil's role in the diffusion of "Was it for this" is far more consequential than that of most poets who do.

Other texts distinguish themselves not only by the extent of their agency but by the variety and centrality of the functional roles they play in the network of diffusion. As we saw earlier, Erskine-Hill proposes Harington's 1591 translation of Ariosto's Orlando Furioso as a possible source for The Prelude: "What was't for this that I in youth thee fed, / With marrow of the Beares and Lions fell?" He might also have remarked Harington's use of the phrase in the "Apologie of Poetrie" that prefaces the translation. After quoting the rebuke of Melissa, who is disguised as Ruggiero's tutor Atlanta, Harington imagines what his own tutor, Samuel Fleming, might say to him upon learning he had Englished Ariosto:

Was it for this, that I read Aristotle and Plato to you, and instructed you so carefully both in Greek and Latin? to have you now become a translator of Italian toyes? ${ }^{47}$

47. Lodovico Ariosto, Orlando furioso in English heroical verse, by Iohn Haringto[n] (London, 1591), viii. 
In a remarkable act of appropriation, Harington transfers "Was it for this" not simply from one heroic poem to another, Aeneid to Orlando Furioso, but from a heroic context to an autobiographical one. The ghost of his tutor laments the betrayed promise of his classical education, the very education that exposed him to books 2 and 4 of the Aeneid and, we might suspect, the phrase "Was it for this"- - very possibly in the translations of Surrey or Stanyhurst. Harington summons this tutelary spirit in order to justify himself and his translation of Ariosto before it. For its part, the Furioso serves (to use a horticultural analogy) as the lattice or truss on which Harington's Virgilian innovations grow and climb.

In using "Was it for this" to reflect on his own education, Harington develops in the phrase a potentiality that Romantic poets would exploit and develop nearly two centuries later. In a short poem entitled "History," for example, Robert Southey imagines the muse of history, Clio, rebuking him for retreating from the cruel deeds of men to the bower of poetic fantasy: "Was it for this I waken'd thy young mind? / Was it for this I made thy swelling heart / Throb at the deeds of Greece, and thy boy's eye / So kindle when that glorious Spartan died?" 48 She speaks to him in the role of a forgotten tutor (like Atlanta or Samuel Fleming), reminding him of his boyish encounter with classical history and its enlivening effect on his youthful emotions and intellect.

When Wordsworth sets out to describe "The Growth of a Poet's Mind," he further expands the educative potentiality of the phrase, transforming it into a Bildungs-block - a way of evoking, reflecting on, and accounting for his spiritual growth (Bildung). Instead of imagining a scolding teacher, he poses the question to himself; instead of formal, institutional education, he depicts the more comprehensive process of self-cultivation in all its forms; instead of the schoolhouse, his study takes place in the grander schoolhouse of Nature. Where Harington appropriates the phrase for a brief discussion of his own life, Wordsworth uses it to inaugurate an autobiographical poem, an epic of the self. As he wrote in a letter to Sir George Beaumont in April of 1805, it was "a thing unprecedented in literary history that a man should talk so much about himself." 49 The phrase spread rapidly in the sixteenth and seventeenth centuries partly because of its association with Virgilian epic; it continued to attract poets in the eighteenth and nineteenth centuries partly because of its association with education and spiritual selfformation.

Harington's functional role in the diffusion of "Was it for this" goes deeper than content. Whereas Surrey and Stanyhurst had fashioned the

48. Robert Southey, "History," in The Annual Anthology, vol. 2 (Bristol, 1800), 88.

49. William Wordsworth, quoted in Jonathan Wordsworth, introduction to The Prelude: The Four Texts (1798, 1799, 1805, 1850), xxv. 
early versions of the English phrase in the project of translation, he first mobilizes it as a formula separable from its initial context of use and transferrable to new contexts. When, in the Ariosto Furioso, Melissa rebukes Ruggiero for his "wanton womanish behavior" (7.42), she does so with the words "È questo dunque il frutto," literally, "Is this then the fruit?" Whether Ariosto is here imitating Virgil is uncertain; that Harington is doing so in his translation, "Was't for this," is clear. Indeed his "Apologie" compares Orlando Furioso to the Aeneid throughout, seeking to legitimize the Italian romance by likening it to the Latin epic. Using a Virgilian English phrase to translate a line of Ariosto is a subtle part of the same justificatory project. When, after quoting Melissa's reproof, he ventriloquizes his tutor Samuel Fleming, he places the phrase's mobile, formulaic character directly before his readers, even those unaware of its Virgilian origins. By repurposing the phrase, he also illustrates the process of standardization in small: the "Was't for this" of the verse translation becomes, in his tutor's prose rebuke, the "Was it for this" that spreads most widely throughout the literature of the next two centuries. ${ }^{50}$ That the phrase could be used as a standard formula was not lost on other poets, like Thomas Collins, who in his 1615 pastoral poem, The teares of loue ("Was it for this, that I did tricke my hayre, / And sought all meanes to make me supreme fayre?") has the distinction of being both the first to adopt the phrase to a woman's toilet, preceding Pope by nearly a century, and the first (though hardly the only poet) to repeat the phrase ad nauseam, six times in twelve lines. ${ }^{51}$ Through sheer, insipid repetition Collins continues the process, begun by Harington, of transforming the phrase into a mobile formula.

\section{HETEROGENEOUS NETWORKS}

The aims and methods of the current investigation are dramatically different from the aims and methods of the scholarly "note." Instead of suggesting a new source or sources, I have sought to sketch a network of diffusion. Instead of explaining the appearance of a phrase in a single poem like The Prelude, I have sought to explain its appearance in English texts prior to 1798. Instead of discovering an earlier use of the phrase through hours, days, weeks, or years of reading with an eye out for echoes and similarities, I have "discovered" a thousand uses of the phrase in the time it took to run a few searches in various digital archives. Discovery, for the methodology of the note, is expensive in terms both of labor and exchange value. Yet because of the outlays of corporations like Google and ProQuest and the labor of numerous programmers, librarians, and typists to create archives of digital

50. To give a rough sense of relative frequency, "Was't for this" appears in only seven searchable texts in EEBO, while "Was it for this" appears in 118.

51. Thomas Collins, The teares of loue; or, Cupids progresse (London, 1615), 42. 
texts, discovery is now cheap. Constructing a network requires that scholars spend labor not on discovery but on arrangement, arranging the discovered uses, so far as possible, in relation to one another. Far from calling down the apocalypse, digital tools make possible a redistribution of labor. Search generates nodes, but it is up to us to connect those nodes, determining their meaning, consequence, and functional relation to one another.

A writer reads a phrase in one or two or more texts and then reproduces it in another text that is read, if she is lucky, by one or two other writers or perhaps more. The collective result of these individual encounters, without which nothing could become common, is an enormous and enormously complex web of associations, what John Law calls a "heterogeneous network." ${ }^{52}$ The network is heterogeneous because its participants are not composed of or reducible to any single kind of entity. Most obviously, a literary network is composed of authors and their texts-texts not only as ideal types but also as the material books that carry them, like the Wordsworth brothers' hand-me-down translation of the Aeneid. Yet authors and texts, which have received most of our attention here, do not begin to exhaust the heterogeneity of the network, which necessarily overlaps with other, complex networks. I have noted the crucial role that English grammar schools played in the spread of "Was it for this" but have left largely uncharted this immense network of pupils and teachers, administrators and parents, as well as an entire economy of official pedagogical texts (textbooks, translations, commentaries, curricula) and unofficial student texts (trots, ponies, cribs, cheat sheets, and so on). As book historians have taught us to see, the material texts by which "Was it for this" was transmitted are products of similarly complex networks of tradesmen, papermakers, printers, publishers, and booksellers, as well as physical objects like presses and paper mills that in turn were constructed by other networks. ${ }^{53}$ All of these entities, linked together through complex associations, contributed in different ways and at different degrees of separation to the spread of "Was it for this."

52. John Law, "Notes on the Theory of the Actor Network: Ordering, Strategy and Heterogeneity," published by the Centre for Science Studies, Lancaster University, http:/ www.comp .lancs.ac.uk/sociology/papers/Law-Notes-on-ANT.pdf.

53. On Wordsworth's access to various libraries and book collections, see appendices 4-7 in Wu, Wordsworth's Reading, 171-86. On the question of material networks, see Robert Darnton, "What Is the History of Books?" Daedalus 111, no. 3 (1982): 65-83. In more recent scholarship Darnton has shifted from discussing circuits to discussing networks, as in Poetry and the Police: Communication Networks in Eighteenth-Century Paris (Cambridge, MA: Belknap Press of Harvard University Press, 2010). My analysis studies diffusion in the print age, but other scholars have explored the way the Internet (the prime example of what Latour calls a "technical network") changes the dynamics of influence. See, e.g., Roger Whitson and Jason Whittaker, William Blake and the Digital Humanities: Collaboration, Participation, and Social Media (New York: Routledge, 2013), esp. 115-63. 
The heterogeneity of the network requires us to reject two kinds of reductionism that have dominated the study of literary influence. The first kind, which I will call personalism, includes any account that disregards relations of influence that are not conceivable as relationships between people. Personalism describes influence solely in terms of friends and lovers, borrowers and stealers, teachers and pupils. The greatest of the personalists is Harold Bloom, who systematically personifies relations of influence. Though the anxiety of influence is primarily textual rather than psychic, "achieved in and by the story, novel, play, poem, or essay" rather than the mind of its author, Bloom practices a "historicism" that, by his own account, "deliberately reduces to the interplay of personalities." 54 "A poem is always a person," he writes, and "a poem is a response to a poem, as a poet is a response to a poet, or a person to his parent." 55 This is why Bloom writes with open derision of "source-hunting" and "allusion-counting," and indeed all studies of influence based on "verbal resemblances." 56 His Freudian family takes no account of the way that writers absorb and reuse material from texts that have no personal or familial resonance, that are neither fathers nor substitutes for fathers, neither sublimations of oedipal desires nor displacements of the primary object of affection. ${ }^{57}$

We can justly call the second kind of reduction impersonalism, though it is most often associated with terms like postmodernism and poststructuralism. The prototypical impersonalists are Julia Kristeva and Roland Barthes, for whom the key term intertextuality does not designate a field of positive inquiry (as it would for many later scholars) but a radical philosophical concept. ${ }^{58}$ Rather than originating in the mind of an individual author, every text is, in the well-known formulation of Barthes, a "tissue of quotations," the compilation or intersection of other texts. ${ }^{59}$ To the extent that an impersonalist speaks of persons, subjects, authors, or agents, it is as effects of texts rather than their causes. Where personalists reduce textuality to persons (poets and their precursors) and relations of influence to relations between persons, impersonalists reduce persons (authors, subjects) to texts and relations of influence to relationships between texts.

54. Harold Bloom, preface to The Anxiety of Influence, 2nd ed. (Oxford University Press, 1997), xiii, and on "historicism," see A Map of Misreading (Oxford University Press, 1975), 71.

55. Bloom, Map of Misreading, 18-19.

56. Ibid., 19.

57. On Bloom's reduction of the plurality of intertexts to that of the predecessor, see Graham Allen, Intertextuality, 2nd ed. (New York: Routledge, 2011), 137.

58. On the development of the concept of intertextuality out of the writings of M. M. Bakhtin, see Julia Kristeva, Desire in Language: A Semiotic Approach to Literature and Art (New York: Columbia University Press, 1980), 64-91.

59. Roland Barthes, "The Death of the Author," in Image, Music, Text (New York: Hill \& Wang, 1977), 146. 
The network approach, by contrast, does not seek to reduce texts to persons, persons to texts, or indeed any kind of entity to any other. Taking its cue from Latour's notion of "irreduction," it aims to see more kinds of agencies-not just the author and the text but all the various nonhuman agents (books, presses, grammar schools, schoolhouses, curricula, etc.) that play a role in diffusion. ${ }^{60}$ The concepts author and text do pose a problem, as they have for the past half century of literary theory, but the problem is not that either is a mere cypher for or effect of the other; rather, like the concept of the source, both are too low resolution to capture the differentiated functional roles of the network of diffusion. For texts we need an elaborate parade of disease reservoirs, lattices and trusses, seed phrases, and Bildungsblocks. For authors we need a mobile army of translators, early and late adopters, formulators, standardizers, and repurposers of all sorts. In the network, the author inevitably has many functions. As long as Bloom's fathers and sons, precursors and ephebes do not drive out all other impersonal roles, there is no reason why they should not assume their distinctive place in the network as well. As with the term source, we need not discard terms like author or text so long as we recognize them as the names of genera containing functionally differentiated species.

Because the network approach seeks to diversify rather than reduce the kinds of visible entities, it must forgo the grand reveal in which Wordsworth is shown to be either, as in M. H. Abrams's personalist reading, the poet who has achieved "a stage of self-coherence, self-awareness, and assured power that is its own reward" or, as in impersonalist accounts, the "Aeolian harp" across which the winds of history and textuality play. ${ }^{61}$ The network neither exalts nor deflates authorial agency but instead multiplies and dislocates it, showing how it is at once constituted, constrained, and enabled by the widest possible range of other agencies. In accord with the impersonalists, Wordsworth is only a node in the network formed by the intersection of edges leading to other nodes. He writes "Was it for this" by quoting it from other texts. In accord with the personalists, authorial nodes are themselves

60. Bruno Latour, The Pasteurization of France, trans. Alan Sheridan and John Law (Cambridge, MA: Harvard University Press, 1988), 212-38.

61. M. H. Abrams, Natural Supernaturalism: Tradition and Revolution in Romantic Literature (New York: Norton, 1971), 96. Wordsworth references the Aeolian harp in the 1850 Prelude 1.96; the "Aeolian lyre," or wind harp, also serves as a central figure for poetic influence in Percy Shelley's Defense of Poetry, in Shelley's Poetry and Prose, ed. Donald H. Reiman and Neil Fraistat (New York: Norton, 2002), 511. See M. H. Abrams, The Mirror and the Lamp: Romantic Theory and the Critical Tradition (Oxford University Press, 1953), 51-52, for the classic account; Timothy Morton, "An Object-Oriented Defense of Poetry," New Literary History 43 (2012): 205-24, for a treatment that seeks to "transcend anthropocentrism" (205); and Thomas L. Hankins and Robert J. Silverman, "The Aeolian Harp and the Romantic Quest of Nature," in Instruments and the Imagination (Princeton University Press, 2014), 101-27, for a study of the harp's role as an actual scientific and musical instrument. 
ineliminable and active constituents of the network. They play real functional roles, creating and structuring the network by exercising agency in concert with various other human and nonhuman agencies. Without nodes, no edges, since authors like Wordsworth work to standardize, formularize, develop, change, and spread "Was it for this." Without edges, no nodes, since Wordsworth only shows up in the network at all because of his relation to other agencies. In the network of diffusion the author is neither dead nor deified, only distributed. ${ }^{62}$

Networks can help us to think about the provenance of poems, but a more radical possibility is that poems can, in some cases, help us to think about networks. Here again, at somewhat greater length, are the opening lines of Wordsworth's draft fragment of 1798, which were, with alterations, incorporated into subsequent revisions of the Prelude:

was it for this

That one, the fairest of all rivers, loved

To blend his murmurs with my nurse's song,

And from his alder shades and rocky falls,

And from his fords and shallows, sent a voice

To intertwine my dreams? For this didst thou,

O Derwent, travelling over the green plains

Near my "sweet birthplace," didst thou, beauteous stream

Make ceaseless music through the night and day

Which with its steady cadence, tempering

Our human waywardness, composed by thoughts

To more than infant softness, giving me

Among the fretful dwellings of mankind,

A knowledge, a dim earnest, of the calm

Which nature breathes among the hills and groves.

(Lines 1-15)

The lines bear witness to the influence of multiple voices, not just the "nurse's song" but the "murmurs" and "ceaseless music" of the river Derwent that "blend" and "intertwine" with the poet's dreams. Wordsworth acknowledges that such agencies, human and nonhuman alike, shaped him right from his "infant softness." And they do not merely speak for themselves, delivering their own messages; in the course of its travels, the Derwent transmits both "knowledge" and a vague pledge ("dim earnest") of "the calm / Which nature breathes," mediating nature's "calm" by means of a "steady cadence." The two-part Prelude of 1799 alters the second half of line 11 from "composed by thoughts" to "composed my thoughts," making

62. On Actor-Network Theory as an attempt to overcome "the agency/structure debate," see Bruno Latour, "On Recalling ANT," Actor Network Theory and After, ed. Iohn Law and Iohn Hassard (Oxford: Blackwell, 1999), 16. 
unmistakable the force of such agencies on the poet's self and, through the connotations of "composed," his writing. In the 1799 poem we are also told, in case we missed it, how "The mind of man is fashioned and built up, / Even as a strain of music" (1.67-68).

Wordsworth's lines, in short, articulate a network far more heterogeneous than the limited one sketched in this essay, illustrating the relative narrowness of the kinds of entities we are able to see and put in meaningful relation. The lines likewise elaborate a set of richly metaphorical, often musical descriptions of the functional associations between agencies, as they blend, intertwine, temper, and compose the poet's mind. "Was it for this" does not simply introduce the poem's recognition and disposition of agencies into a network, it also represents an agency in its own right, one that speaks (in contrast to the "nurse's song," which is marked as a naive, feminine, folk melody) with the voice of an educated, masculine, humanist literary elite. The phrase is the key point of contact between the small but heterogeneous network described within the poem and the larger, though necessarily more homogeneous network-of poets and poems, translators and translations, texts and books, publishers, printers, and grammar schools-in which the Prelude is but a single node. Wordsworth's lines challenge us to explain how we can understand these two disparate networks as finally one and the same. It is difficult enough to conceive of a network of diffusion that includes entities as heterogeneous as John Harington, the volume of Pitt's Aeneid owned by the Wordsworths, and Hawkshead Grammar School. ${ }^{63}$ But how, without lapsing into incoherence, could such a network also comprise the river Derwent? Though the digital archive puts us in a position to ask this kind of question in a detailed and meaningful way, it is no more capable of providing an answer than the print tools used by earlier scholars. The study of influence has yet to "touch apocalypse" as Bloom prophesied, but it remains in need of further revelation.

63. In the terms of network science, this is the problem of "multimodal" or "multipartite" networks, which become increasingly resistant to analysis, and especially quantitative characterization, as the number of node types increases. On multimodal networks in humanities research, see Scott Weingart, "Networks Demystified 9: Bimodal Networks," The Scottbot Irregular (blog), January 21, 2015, www.scottbot.net/HIAL/?p=41158. 